\title{
Song Dynasty Gate Structure and Its Typology Reflected in the Paintings of Chinese Artists of $10^{\text {th }}$ $13^{\text {th }}$ Centuries*
}

\author{
Marianna Shevchenko \\ Moscow Institute of Architecture (State Academy) \\ Scientific Research Institute of Theory and History of Architecture and Urban Planning \\ Moscow, Russia \\ E-mail: marianna-sh@yandex.ru
}

\begin{abstract}
In Chinese architecture, gate structures have always served as an indicator of the status of the owner and the rank of the entire complex. Unfortunately, since the time of the Song Dynasty very few gates have been preserved up to the present day, and mostly they belong to the monastery gates. However, Song dynasty paintings and frescoes show a welldeveloped typology of the gates and diversity in form. Besides different constructive and decorative elements, used in the Song dynasty gates structures are presented in detail in Song paintings. The analysis of the depiction of the entrance buildings on the scrolls and the frescoes of the 10 th -13 th centuries allows us to expand existing understanding about the typology, constructions and decoration of the gates of that period.
\end{abstract}

Keywords-gate structures; typology of the gates; rank system; Song Dynasty; Chinese architecture

\section{INTRODUCTION}

The planning stereotype of architectural complexes with inner courtyards was used in architecture of China from the ancient times. The simplest courtyard was surrounded by buildings at four sides and was called a fourfold yard siheyuan (四合院). The enclosed courtyards were used in buildings of various purposes: palaces, monasteries, tombs, dwellings, etc. Depending on the size of the complex, there could be a large amount of such courtyards on its territory. However, all the buildings of the fourfold yard were hidden behind blind walls, and only the gates were accessible to the view. Therefore the gate structure was perceived as the most important structure of the entire architectural complex [1].

This led to the fact that the form of the gate became more significant. In the Han dynasty's "Kao-Gong-Ji" treatise there was already a regulation concerning the size of the gates of palaces and cities [2]. After developing the

*The Reported study was Funded by Science and Technology Development State Program of the Russian Federation for years 2013-2020 Program of Fundamental Research of State Academies of Science for years 2013-2020, within the Program of Fundamental Researches of Ministry of Construction, Housing and Utilities of the Russian Federation and Russian Academy of Architecture and Construction Sciences; the Research Project 1.2.1. ranking system for government officials in Imperial China, different requirements to the forms of the gate structures of their residences have emerged. According to the rank system of the Tang dynasty (618-907 A.D.), government officials of rank three or higher were allowed to build a three-bay gate structures covered with two-slope roofs of xuanshan (悬山) type [3]. A special room for the gatekeepers could be arranged behind the gates of particularly large residences. One family could have several high rank court officials. In this case behind the residence's main gates the additional gates with a name of the official and his insignia were placed.

Almost without exception, all remaining gate structures of the Song and its contemporary dynasties of Liao and Jin belong to the monastery complexes. These gates are mainly rectangular hall-type wooden structures. However the Song dynasty paintings and frescoes of $10^{\text {th }}-13$ th centuries provide a wealth of material considering typology, forms and decoration of the gates. Depictions of architecture features in the Song, Liao and Jin dynasties paintings were analyzed by numerous researches, in particular, Liang Sicheng, Fu Xinian, Wang Guixiang, Fu Boxing, Pan Guxi etc. However, their study was not focused on the typology and construction of the gates. In this article we examine only the Song dynasty structure types that did not survive to this day and that are remaining only in paintings, for this makes it possible to expand and generalize existing ideas about the structure of the Song dynasty gate buildings.

\section{TERRACE-TYPE GATE}

In Chinese architecture, buildings with a tall lower part made of rammed earth with no internal room space are commonly referred as terrace-type structures. The upper part of such buildings can either be an open terrace, or be built-up with wooden pavilions.

A city of Bianjing (modern Kaifeng) with an Imperial palace in its center was a capital of the Northern Song dynasty. Drawings of only one palace structure remain to this day - a Xuandemen main gates. These gates are portrayed on a famous drawing by Emperor Huizong "Cranes" drawn in the year of 1112 "Fig. 1". In addition, there is a schematic 
relief of this gate on a bronze bell of the Northern Song dynasty kept in a Liaoning province museum nowadays "Fig. $2 "$.

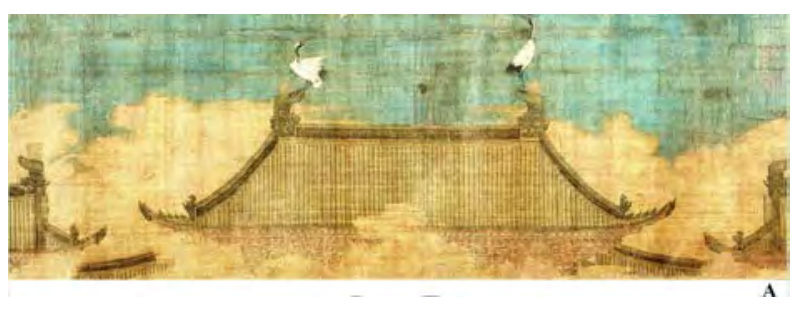

Fig. 1. ZA - Zhao Ji (Hui-zong emperor) "Cranes" ${ }^{1}$, fragment.

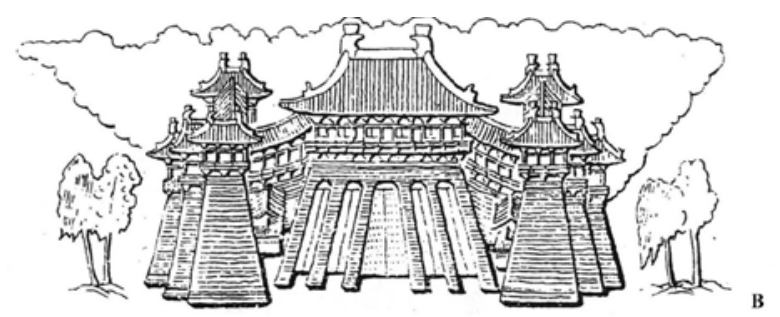

Fig. 2. Relief of the Xuandemen gate on a bronze bell of the Northern Song dynasty [4].

In Huizong's drawing we can see a quite intricate image of the upper part of the central gate building. Based on this image we may conclude that the gate building had foursloped roof, while its eaves were supported by six-tier dougong (斗栱) bracketing clusters. This indicates a high rank of the gate complex "Fig. 3". Moreover, a form of chiwei (紼尾) roof elements may prove to be rather interesting to us "Fig. 4". Very few such elements have remained intact until modern days since the 12th century, for they were usually first to deteriorate and be replaced during maintenance of the buildings. Perhaps, most famous chiwei elements of similar time period are that of the main temple of the upper monastery of Huayansi in Datong city which are dated back to the year in 1140 of Jin dynasty [5]. Chiwei elements of a given type were allowed to be placed strictly on highest rank buildings [6] such as main imperial palace structures or main temples of prominent monasteries.

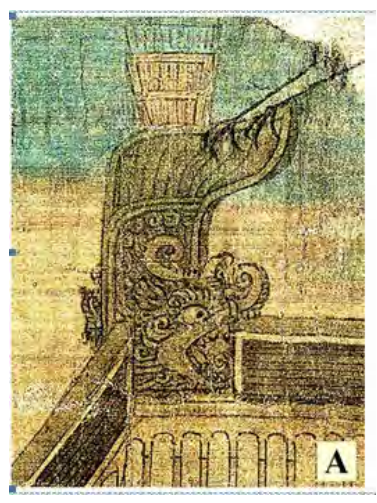

Fig. 3. Xuandemen gate details: chiwei element.

Zhao Ji 赵佶 (1082-1135), “Cranes” (瑞鹤图), Northern Song dynasty, 1112 A.D., Liaoning province museum.

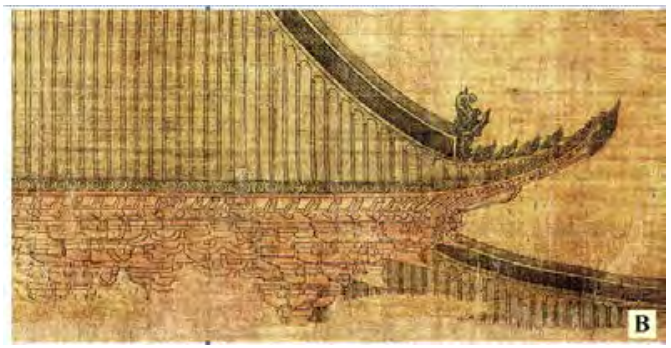

Fig. 4. Xuandemen gate details: six-tier dou-gong bracketing cluster.

Based on bronze bell relief we can see that the gates itself were a complex structure which consisted of gate building and tall gate towers to the sides. Such typology can be traced back to an ancient tradition of Han dynasty (206 B.C. - 220 A.D.) when the gates of a major structure were provided with que (阙) gate towers to highlight its importance [7]. This tradition continued in Tang dynasty (618 - 907 A.D.) as well when side gate towers were often connected to the central gate building by use of galleries or city walls. A fresco in Mogao cave N9 can serve as a good example of this "Fig. 5". A high terrace with a gate building on top of it is in the center of the gate complex with two symmetrical towers to the sides.

A structure of the Xuandemen gates is as follows: two inclined galleries connect side gate towers to its central gate building. Shapes of gate towers are of complex nature: larger gate towers are complemented by two sets of smaller ones. Such typology can also be traced back to ancient gateways of the Han dynasty as well.

Based on bronze bell relief and gate depictions in "Dongjing Menghualu" chronicles we can presume that Xuandemen gates had five gateways - which is a maximum amount of gateways allowed to be built in Chinese palace gates and it clearly indicates exceptional significance of these gates. 

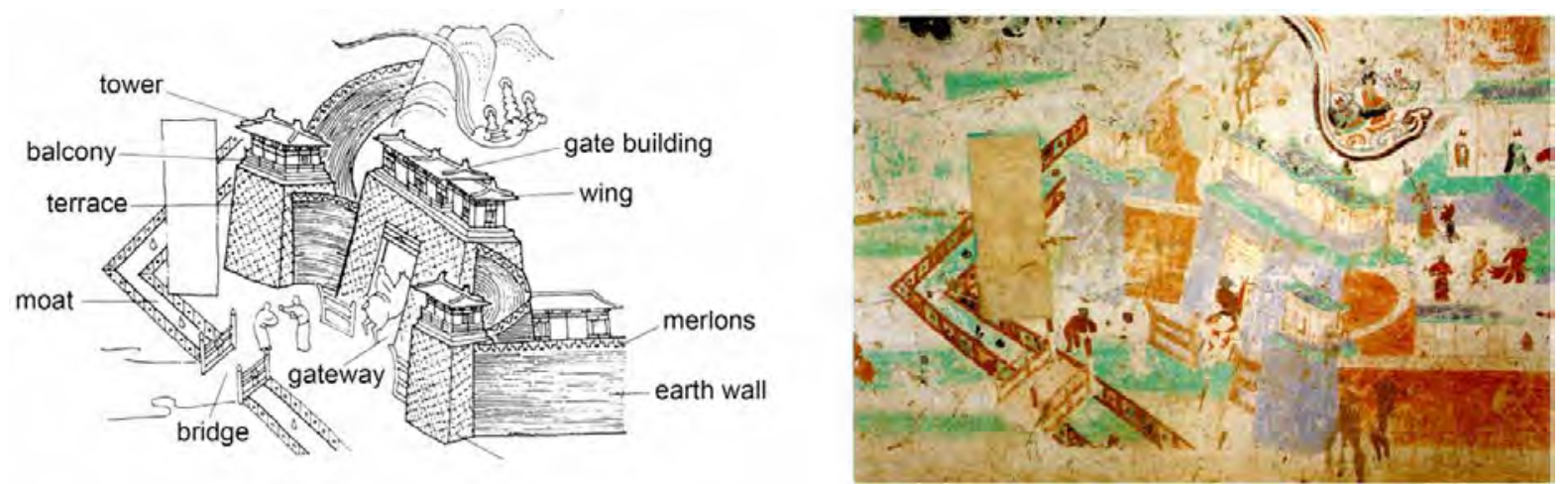

Fig. 5. Fresco on the southern wall in Mogao cave N9, Late Tang (875-907 A.D.) [8].

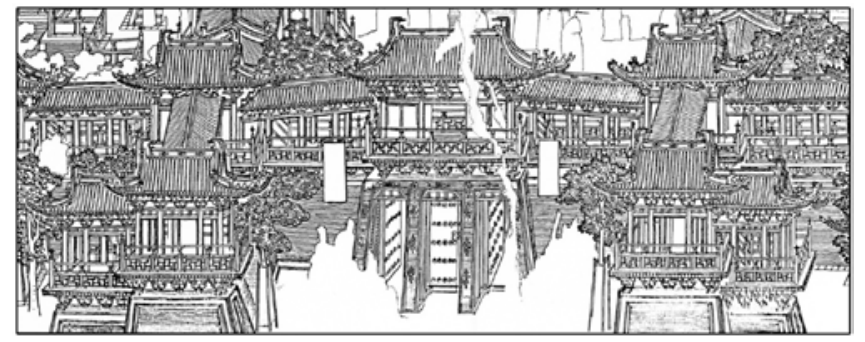

Fig. 6. Fresco in the southern hall of Yangshansi monastery, Jin dynasty (1167 A.D.) [4], fragment.

Same structure, but of a smaller scale, can be seen on a fresco in the southern hall of Yangshansi (岩山寺) monastery in Shanxi province "Fig. 6". There are three gateways and a central gate building above in the center. Two L-shaped galleries connect side gate towers to the central gate building. Larger side gate towers are complemented with just one set of smaller towers in contrast to Xuandemen gates. The gate building roof is four-sloped with six-tier bracketing clusters, both gate tower have 9-ridge roofs which is similar to that of Xuandemen gates.

Song dynasty "Yingzao Fashi” treatise delves into a great detail on structure forms that indicate structure's rank [9]. However, main gate complex rank differences are not mentioned there. Based on Emperor Huizong's drawing and Yangshansi monastery fresco we can presume that given structures differ in ranks with the Xuandemen gates rank being somewhat higher. The main indications of its rank are a number of gateways and complex shapes of side gate towers. If we continue with this line of thought we may conclude that gates depicted in the fresco in Mogao cave N9 fall into an even lower structure rank for they have only one gateway and a very simple shape of side gate towers.

Later on, terrace-type gate typology continued its development and Wumen gates in Gugong imperial palace in Beijing may serve as a most prominent example of it [10].

Despite common to the Tang and Song dynasties gateways not of cylindrical, but of trapezoidal shape, tunnel vaults were not unknown to China since the Western Han dynasty, albeit used mostly in underground funeral complexes. Arched gateways started to arise only in
Mongolian Yuan dynasty [10] and became widely accepted in $14^{\text {th }}$ century Ming dynasty.

Song dynasty paintings depict city gates as well. A southeastern city gates of Bianjing are depicted on a $12^{\text {th }}$ century artist Zhang Zeduan's painting “Along the river during the Qingming festival" "Fig. 7" 2. Although the gates on a painting were not main gates of the city, nevertheless, they represent in itself quite an impressive structure. A wooden gate building is towering on top of a high brick paved terrace. There is only one trapezoidal gateway. According to the scale of humans and animals drawn to a painting we can estimate gateway height to be more than 5 meters. Main terrace is adjoined by two smaller terraces with steep one-flight staircases.

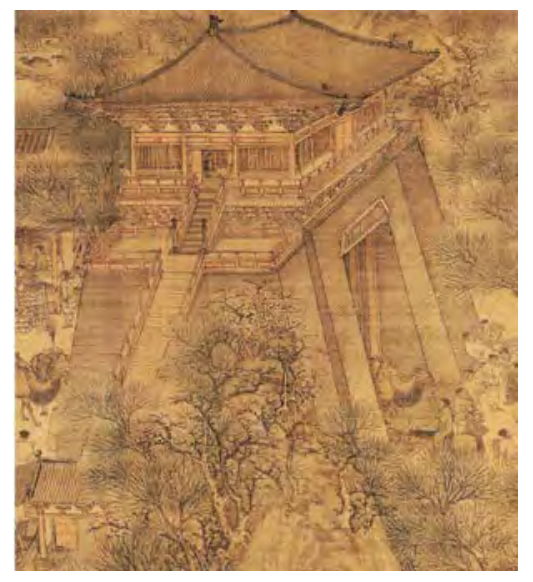

Fig. 7. Zhang Zeduan "Along the river during the Qingming festival”, fragment.

Gate building is placed on a high base decorated with dou-gong bracketing clusters - a so called balcony. The balcony was considered to be a mandatory part of any towerlike structure in China. Few completely wooden structures of this type have remained to this day since 11-13th centuries. Here, however, the structure on the painting is of a mixed composition: lower part is constructed from rammed earth

\footnotetext{
2 Zhang Zeduan 张择端 (years of life are unknown), “Along the river during the Qingming festival” (清明上河图), Northern Song dynasty, The Palace Museum in Beijing.
} 
and is covered with bricks, while the upper part is made out of wood. Nevertheless, the structure of the balcony of the gate building is no different from completely wooden tower counterparts. Bracketing clusters used here are six-tier clusters. This indicates a high rank given to this structure as a city gate of a capital despite its location. Bracketing clusters support the balcony that girdles around the entire gate building. A standard wooden balcony railings, described in "Yingzao Fashi" are used on the balcony [11]. A roof of the gate building is four-sloped. Its eaves are supported by large seven-tier dou-gong bracketing clusters. It is peculiar that secondary city gates had a higher number of bracketing clusters than that of imperial palace main gates. This complies with "Kao-Gong-Ji" treatise's regulations that prescribe city gates to possess higher rank than the gates of the imperial palace [2]. Yet, much simpler shapes of the gate indicate its secondary place in a system of city gates.

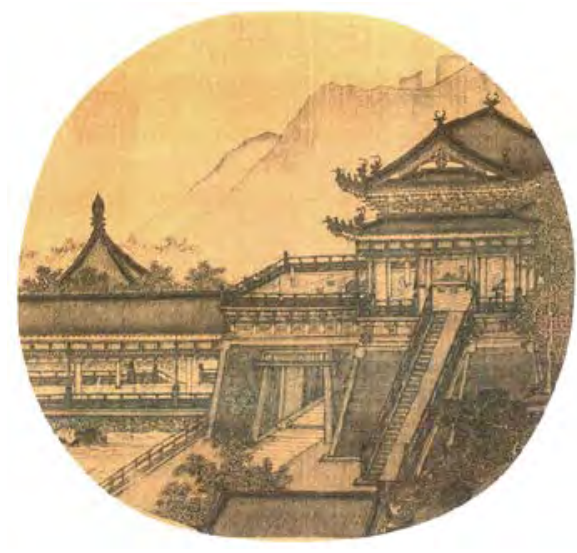

Fig. 8. Li Song, "Begging for a cleverness in Han palace”, Song dynasty.

Another interesting palace gates depiction can be found on Li Song's fan painting "Begging for a cleverness in Han palace” "Fig. 8"3. Gate building depicted here is similar in its structure to the one described above. Its gateway, however, is placed not directly below gate building, but under its protruding terrace. It is a quite unorthodox composition. The terrace, according to the title of the drawing, would serve not only for observing the scenery, but also for certain ritual purposes. It is supported by a belt of dou-gong bracketing clusters that is different from the standard balcony structure. The difference is in small supporting pillars placed below each cluster and engraved ceramic tiles set in between these pillars. This practice is characteristic of stylobate structure. Meanwhile, the structure of a balcony under the gate building is the same as in Zhang Zeduan's painting with just fewer amount of bracketing clusters tiers used here - there are only five tiers.

A roof of the gate building is 9-ridged, chiwei elements are different from what is displayed above. All this indicates a medium structure rank: 9-ridged roofs are inferior to foursloped roofs and chiwei of a given type can be seen on less

\footnotetext{
3 Li Song 李嵩 (1166-1243 A.D.), “Begging for a cleverness in
} Han palace” (汉宫乞巧图), Southern Song dynasty, the Palace Museum in Beijing. important secondary palace and mansion structures [4]. Besides, bracketing clusters are rather small in this structure: five-tier under balcony and six-tier clusters under roof eaves. In the middle of a staircase leading to the gate building, however, we can see an inclined flat stone plate that would normally see its usage only in imperial palace structures. Therefore, we can make a conclusion that the structure depicted on the fan painting was a secondary entrance structure of an imperial palace.

Door leaves of all gates mentioned above are decorated with doornails which comply with ban-men (板门) door type [12]. Such door type remains only in Wenshudian (文殊殿) ${ }^{4}$ temple of Foguangsi monastery and in a main temple of Huayansi (华严寺) ${ }^{5}$ monastery in Datong city. During relevant time period doornails were used to fix door panels to horizontal planks. This made gate doors highly durable therefore, its structure rank was high. Subsequently, during the Ming and Qing dynasties doornails, albeit still in use, lost their functionality and become more of a just decorative element [5].

\section{HALL-TYPE GATE}

Hall-type gate is a most common type of gates. They may serve as an entrance to residential, administrative, religious, funeral and park complexes. All remaining gates of the Song, Liao and Jin dynasties are of this type. As a rule, the halltype gates are a simple rectangular structure with door leaves fixed between the central pillars. Depending on the entire complexes' rank, such gates may differ in the number of bays, the shape of the roof, type of door leafs, as well as the constructive and decorative details.

However the Song dynasty paintings show more complex forms of the hall-type gates. For instance, here we can see an elongated gate structures with two wings attached to the central hall. In the gate wings a pair of doors could be installed, as shown in the painting "Along the River During the Qingming Festival" "Fig. 9", or lattice windows, as in the depiction of an ancestral temple [13] in the Qingxi Park in Jiankang city (modern Nanjing).

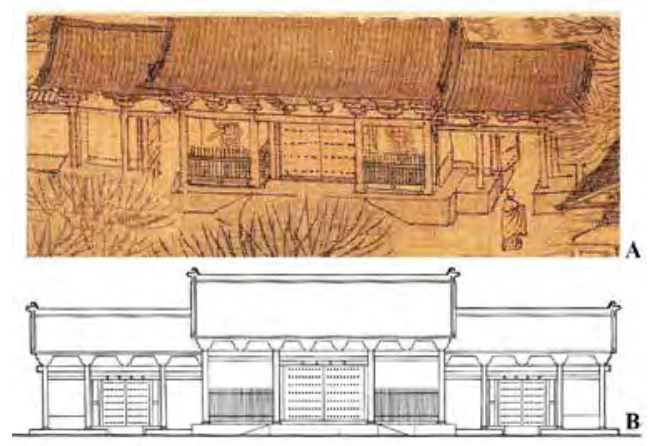

Fig. 9. Gate of the Buddhist monastery in the scroll "Along the River During the Qingming Festival”: A - fragment of the scroll; B reconstruction by Pan Guxi [12].

\footnotetext{
Jin dynasty (1115-1234 A.D.), year of construction - 1137 A.D.
} Jin dynasty (1115-1234 A.D.), year of construction - 1140 A.D. 
The gate depicted on the Zhang Zeduan's scroll leads to a Buddhist monastery, as indicated by the figure of the monk, as well as the statues of Vajra spirits installed in the main hall. Central three-bay structure is covered with a two-slope roof of xuanshan type. The roof is supported by five-tier dou-gong bracketing clusters. A ramp leads to the central gateway. Side wings have three bays as well, with smaller two-leaves-doors installed in their middle bay. Door leaves are decorated with doornails. Under the whole gate structure, there is a stylobate, however, it is absent under the side gateways. This was done for the convenience of passage of horse riders and wagons.

Zhang Zeduan's painting shows several hall-type gates with only one bay. One of those gates is located outside the city wall. It belonged to the garrison of the capital's city guards "Fig. 10". Another gate of that type is depicted inside the city walls, in a commercial quarter of Bianjing "Fig. 11". Most likely, the gates led into the residential courtyard, which belonged to the pharmacist, whose shop was located in the nearby [14].

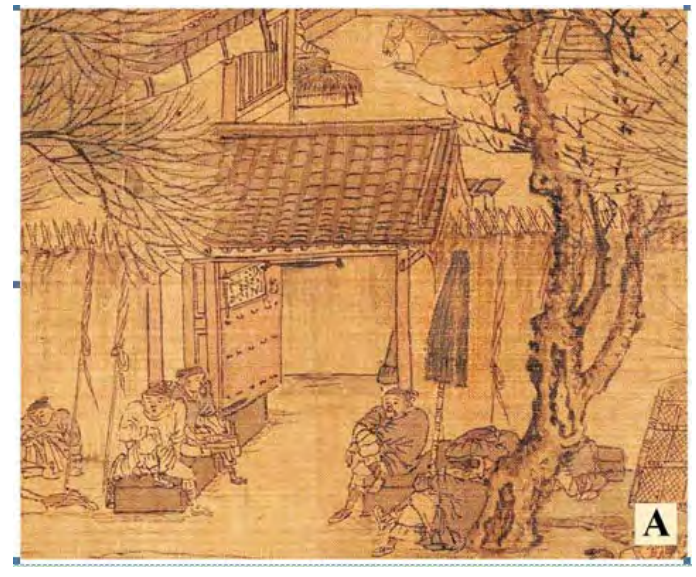

Fig. 10. Hall-type gate with one bay: gate to city guard's garrison.

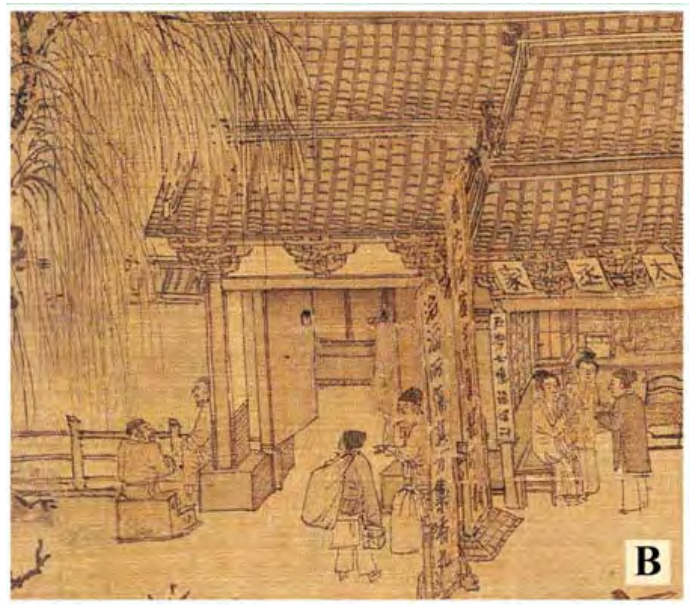

Fig. 11. Hall-type gate with one bay: gate to the residence of a merchant.

Despite these two gates belong to the same gate type their forms indicate a different function. The shapes of the garrison gate are rather simple: there is no rich decoration, and even no dou-gong bracketing clusters. This suggests that either this is a secondary gate, or, if this is the only gate, the garrison itself was rather small and insignificant in the structure of the city's guard detachments. However, despite all the modesty of the forms of this structure, the door leaves were still covered with red lacquer and decorated with the doornails. This clearly indicated that it was a certain municipal department's gate.

Second gates led into the residential courtyard. They were richly decorated. Here we can see quite large five-tier dou-gong bracketing clusters and chiwei elements at the ends of the roof ridge. All this points out the welfare of the owner. According to the Song dynasty's regulations the merchants were not allowed to use dou-gong in their gate structures [15]. However, with the growth of welfare, this rule became often violated. This, in particular, is evidenced by the merchant tombs of that time. Therefore the presence of brackets on this gate does not mean that it is an official's residence. The southeast area of Bianjing, shown in the picture of Zhang Zeduan, was located far from the central street and imperial palace. It was a commercial district [14]. The fact that the owner did not have a high social status is indicated also by lack of doornails on the door leaves. Simple leaves were most probably of ruan-men (软门) [12] door type, which was less durable than the ban-men door type.

Both gates have no stylobate under the doors, which means it was possible for horses and wagons to pass through. This is confirmed by the figure of the horse in the guard's courtyard. In front of the garrison gate there are quite high stone blocks, and in front of the residential gate there is a stone with stairs. Those stones served for the convenience of horse saddling [16].

\section{WUTOUMEN GATE}

Another well-known type of gates in medieval China was the wutoumen (乌头门) gate. These gates were mainly made of wood, therefore they were not preserved untill the present day. However, there are numerous depictions of wutoumen gates in the Song paintings and treatises. The earliest mention of the wutoumen gates is contained in the Tang Dynasty's "Tang Liudian" book, where it is said that officials above $5^{\text {th }}$ grade are allowed to construct a wutoumen gate [3]. During the Song dynasty this type of gates continued to be actively used, and, apparently, their purpose remained the same: they served as an indicator of the social status of the owner. 


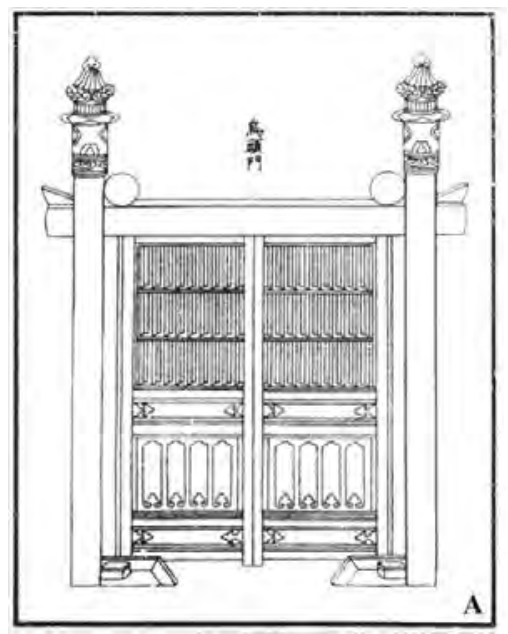

Fig. 12. Wutoumen gate: depiction from “Ingzao Fashi” treatise.
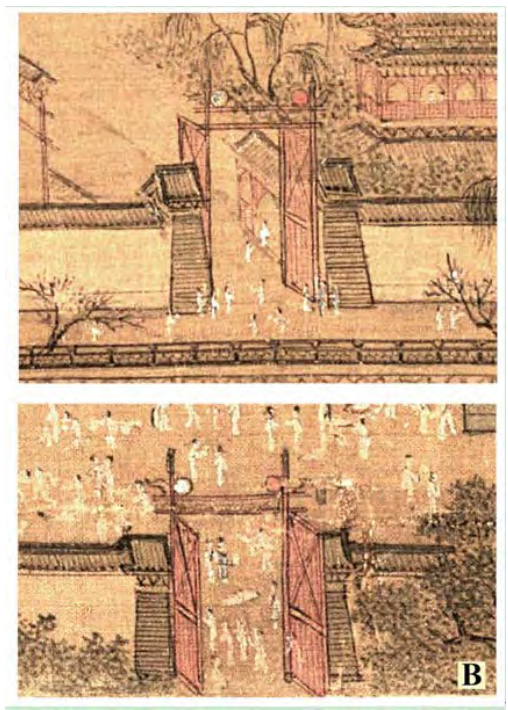

Fig. 13. Wutoumen gate: depiction in scroll "Regatta in Jinmingchi Lake", Southern Song dynasty ${ }^{6}$.

The image of the gate is presented in the illustrated annex to the treatise "Yingzao Fashi” [9] "Fig. 12". It is a simply shaped wooden structure, which consisted of two pillars, upper beam and door leaves. The distinctive feature of wutoumen gate was that its pillars towered above the beam, and upper part of the pillars was covered in relief depicting aconite flowers - the wutou (乌头), that is where the name wutoumen comes from originally. In addition, the schematic shapes of moon, sun and clouds were placed on top of the gate to the side of the pillars. In the scroll "Regatta in Jinmingchi Lake" we can see several depictions of the wutoumen gate type "Fig. 13". Their forms fully correspond to the depiction in the treatise. This suggests that typology of the wutoumen gate wall was well developed and widely

6 “Regatta in Jinmingchi Lake” (金明池争标图), Museum of Tianjin. This scroll has signature - Zhang Zeduan, however his authorship has been widely questioned. Many scholars believe that this is a copy of Zhang Zeduan’s scroll from Southern Song dynasty. known in the Song dynasty. Paintings show also thee-bay wutoumen gate, we can see it in the Li Tang's scroll "Duke Wen of Jin Recovering His State” 7 "Fig. 14".

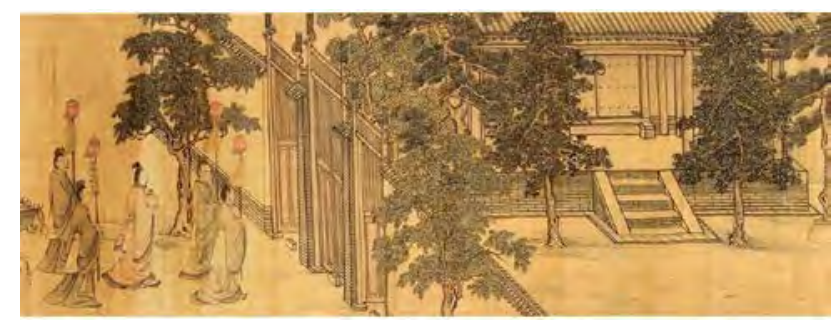

Fig. 14. Li Tang (1066-1150), "Duke Wen of Jin Recovering His State", fragment.

During the Song dynasty the wutoumen gate type developed into the lingxingmen (棪星门) gate type [17]. The shape of that gate type was quite similar, albeit lingxingmen gates were mainly placed in religious and funeral complexes. Later, stone starts to be used as a primary construction material. Eventually, the wutoumen gates were abandoned, while the lingxingmen gate type saw its wide use in the Ming and Qing architectural complexes.

The wutoumen gates did not have a protective function, they only indicated a rank of the complex. Behind wutoumen gates a main hall-type gate with firm door leaves would usually be constructed. Practically, it could only be done when a second outer wall was to be erected around the residence. It is shown in the Li Tang's scroll "Fig. 14", where we can see a three-bay hall-type gate with ban-men doors behind the wutoumen gates. However, this tradition emerged well before the Song dynasty, as evidenced by a Tang fresco from the cave N23 of Mogao complex "Fig. 15" [8].

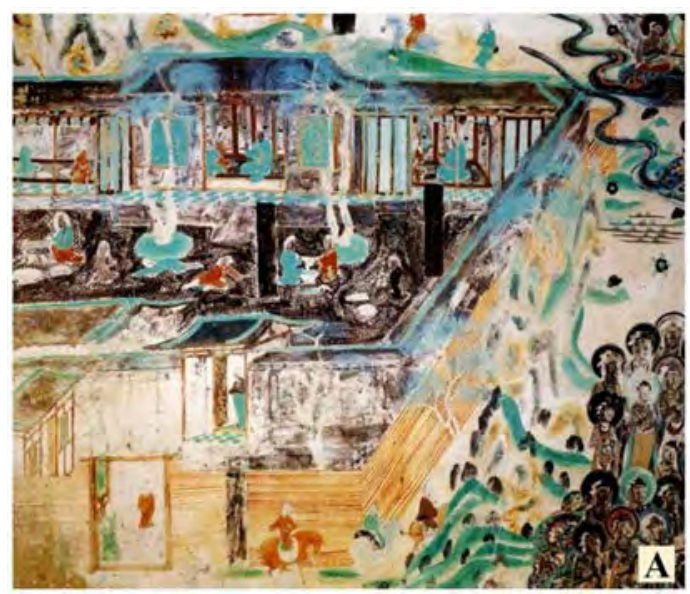

Fig. 15. Fresco from the cave N23 of Mogao complex, Tang dynasty, fragment.

\footnotetext{
7 Li Tang 李唐 (1066-1150), “Duke Wen of Jin Recovering His State” (晋文公复国图), Southern Song dynasty, The Metropolitan Museum of Art, USA.
} 


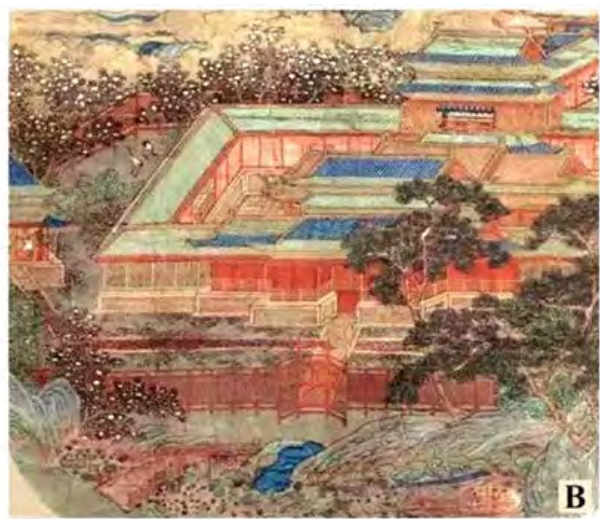

Fig. 16. Unknown artist. “Lotus fragrance in a secluded garden” (曲院莲香 图), Southern Song dynasty, fragment.

Somewhat similar depiction is shown in the fan painting "Lotus fragrance in a secluded garden” "Fig. 16 " [16]. Here we can see a rich residence, surrounded by a translucent thin fence with a gate in the center in addition to the main wall. But in this depiction, the outer gate has a small roof with raised angles. This is not the classical wutoumen shape, but some kind of intermediate form between the wutoumen gate and the pailou arch which is described below.

\section{PAILOU ARCH}

Pailou (牌楼) arches are rooted in wutoumen gate type. A large number of wooden, brick and stone pailou gates of the Ming and Qing dynasties survived to the present day. However, pailou from earlier dynasties have been lost. Pailou arches were usually located in front of the gates to the architectural complexes of various uses: residential, funeral, park, palace, religious complexes and also at intersections of city streets. As a rule, name of the quarter or complex was inscribed on top of pailou, but there could also be a famous poetic expression written as well [1]. Apparently pailou arches appear not earlier than the Song dynasty [16]. Neither the texts of the Tang dynasty, nor paintings, nor frescoes give us evidence of the existence of such structures. However, during the Song dynasty pailou arches have already been widespread, as attested by the historical chronicles of that period, and numerous paintings.

The pailou placed on the city street is depicted in "Regatta in Jinmingchi Lake" painting. There we can see an arch with the name of Qionglinyuan (琼林园) park in it "Fig. 17 ". It is a one-bay arch, covered with a tile roof. Roof is supported by five-tier dou-gong bracketing clusters in total amount of four clusters. Main ridge is decorated with chiwei roof elements. Pillars are painted red. To stabilize the arch, the four inclined braces are attached to the pillars. In general, the shape of that arch is almost identical to the later samples.

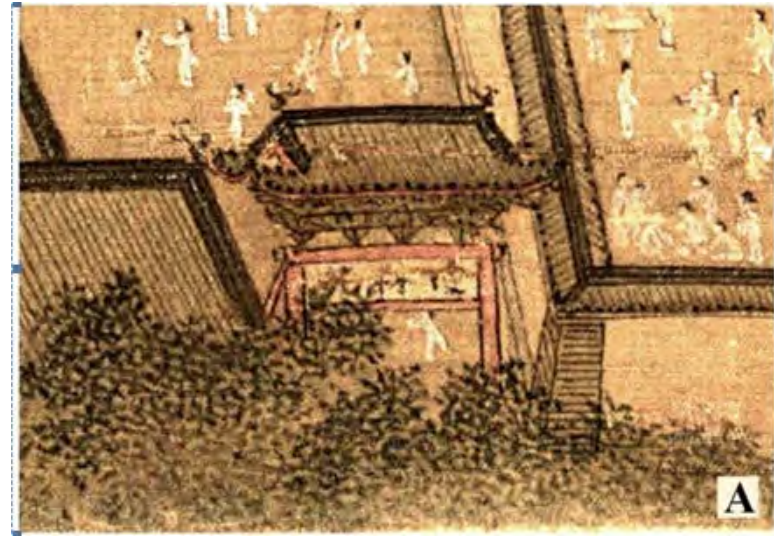

Fig. 17. Pailou arches, shown on Southern Song paintings: "Regatta in Jinmingchi Lake”.

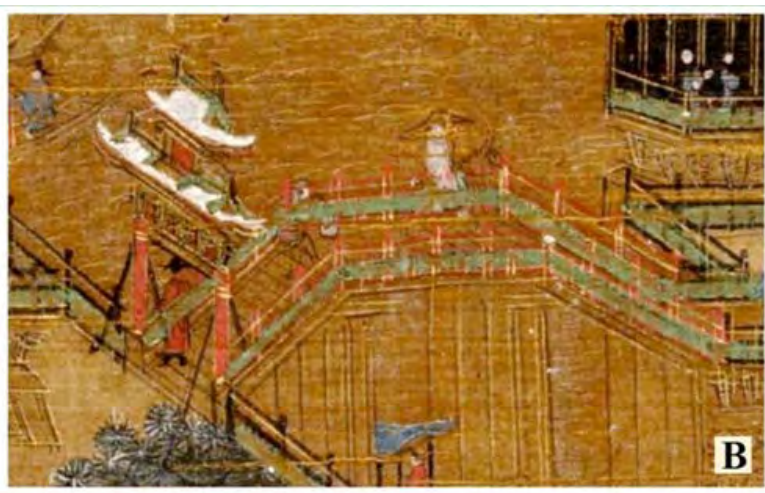

Fig. 18. Pailou arches, shown on Southern Song paintings: "Blessed snow in the capital".

Besides, there are depictions of pailou arches, placed inside the architectural complexes. For instance a rather complex shape arch is depicted in a "Blessed snow in the capital" ${ }^{8}$ picture "Fig. 18". It has three small roofs, while a central roof is higher that two side roofs. The arch is supported by four thin braces for the stability. The pailou is placed in front of a bridge - such a composition was widely used later, in the park ensembles of the Ming and Qing dynasties. The painting is signed by the name of the famous Tang dynasty artist Li Sixun (李思训). However, many researchers, relying on the features of the depicted buildings, and, in particular, the presence of the pailou arch, conclude that this picture belongs to the Southern Song Dynasty [16]. Thus, the depiction of the gate structures allows us, among other things, to specify the dating of paintings.

\section{CONCLUSION}

Analysis of the Song dynasty paintings allowed us to draw several important conclusions about the characteristics of entrance structures of that period.

We have clarified and systematized a typology of entrance structures depending on their structure

\footnotetext{
8 Unknown artist, “Blessed snow in the capital” (京畿瑞雪图纨
} 扇), Southern Song dynasty (?), The Palace Museum in Beijing. 
characteristics. Several following entrance structure types were identified: terrace-type, hall-type, wutoumen and pailou types. Field of application of every entrance structure type is shown according to structure's rank and importance of the entire architectural complex.

Rank differences of the Song dynasty city and palace gates were studied and characteristics that indicate their rank were defined as following: roof shape, side gate tower shape, amount of dou-gong cluster tiers, chiwei element shape and door leaves type.

Typology of hall-gates and their shapes were examined. It was shown that the shape the gates not only would indicate a social rank of the owner, but, in some cases, it also pointed to owner's financial prosperity despite his low social rank.

Typologies of wutoumen gates and pailou arches were examined and consistency of their development and shape similarity was illustrated.

In general, a given research has shown that a systematic analysis of architectural objects on the Song paintings allows us to fill existing gaps in evidence-based surveys on typology and structure of separate buildings.

\section{REFERENCES}

[1] Lou Qingxi. "Twenty lectures on ancient architecture of China”, Moscow: ASV Press, 2010, p. 13, 36.

[2] Dai Wusan. "Illustrated "Kao-Gong-Ji" treatise”. Jinan: Shandong Xinhua Press, 2003. p. 80.

[3] Zhang Jiuling. "Tang-Liu-Dian", Tang dynasty, Vol. 23, URL: https://ctext.org/wiki.pl?if=en\&chapter=812923.

[4] Go Daiheng. "History of Chinese architecture”, Vol.3, Beijing: China Architecture and Building Press, 2009, p.115, 138, 813-815.

[5] Liang Sicheng. "History of Chinese architecture", Tianjin: Baihua Art and Literature Press, 1998, p. 214, 219.

[6] Guo Qinghua. The mingqi pottery buildings of Han dynasty China. Toronto: Sussex Academic Press, 2016, p.149-150.

[7] Wang Guixiang. "Discussions on the ancient Chinese architecture", Beijing: China Architecture and Building Press, 2015, p.11-13.

[8] Sun Ruxian, Sun Yihua. "Complete review of Dunhuang caves", Vol.21, Hong Kong: Commercial Press, 2001, p. 221, p.170, 274).

[9] Li Jie. "Yingzao Fashi", Song dynasty, Vol. 4, 32). URL: https://ctext.org/wiki.pl?if=en\&res=716382.

[10] Pan Guxi. "History of Chinese architecture", Vol.4, Beijing: China Architecture and Building Press, 2009, p.126, 379.

[11] Liang Sicheng. "Complete collection of works", Vol.7, Beijing: China Architecture and Building Press, 2001. p. 320, 373.

[12] [Pan Guxi, He Jianzhong. "Research on the "Yingzao Fashi" treatise". Nanjing: Southeast University Press, 2005, p.110, 111.

[13] Zhou Yinghe. “Jingding Jiankangzhi”, Song dynasty, Vol.5). URL: https://ctext.org/library.pl?if=en\&file=9962\&page=69.

[14] Zhu Jin, Pan Jianzhong, Zhu Xiaofeng. "Analysis of development features of Dongjing's commercial space in Northern Song Dynasty: based on interpretation of drawings of Riverside scene at Qingming Festival”, City Planning Review, Vol.37, No.5, May 2013, p. 48-52.

[15] Liu Dunzhen. "History of Chinese architecture", second edition, Beijing: China Architecture and Building Press, 2003, p.238.

[16] Fu Boxing. "Southern Song dynasty architecture reflected in Song paintings", Hangzhou: Xiling Seal Engraver's Society Publishing House, 2011, p. 10, 63, 177.
[17] Meng Yuanlao. "The eastern capital: a dream of splendor”, Song dynasty, $\quad$ Vol. $\quad 5, \quad$ 7) URL https://ctext.org/wiki.pl?if=en\&chapter=104237. 